\title{
Pengaruh Limbah Pemanenan Kayu Terhadap Efisiensi Pemanfaatan Kayu Hutan Produksi Alam Pada Dua Pengusahaan Hutan di Kalimantan
}

\author{
Sona Suhartana and Yuniawati
}

Pusat Penelitian \& Pengembangan Hasil Hutan Jl. Gunung Batu No. 5 Bogor 16610. Telp/Faks: (0251) 8633378, (0251) 8633413

*Author Korespondensi: Email: sona.suhartana@gmail.com ,yunia_las@yahoo.co.id.

\begin{abstract}
ABSTRAK
Potensi limbah akibat pemanenan kayu sampai saat ini masih cenderung tinggi yang dapat menyebabkan rendahnya efisiensi pemanfaatan kayu. Hal ini sebagai kecenderungan pemborosan bahan baku kayu, sedangkan saat ini terjadi ketimpangan antara ketersediaan bahan baku yang terus menurun dengan kebutuhan kayu untuk industri. Tujuan penelitian adalah untuk mengetahui potensi limbah pemanenan kayu pada dua pengusahaan hutan di Kalimantan dan pengaruhnya terhadap efisiensi pemanfaatan kayu. Metodologi penelitian dengan mengukur potensi tegakan, volume kayu yang dimanfaatkan, volume limbah kayu setelah pemanenan kayu, menghitung indeks tebang, indeks sarad dan efisiensi pemanfaatan kayu. Hasil penelitian menunjukkan bahwa: (1). Rata-rata volume kayu yang dimanfaatkan pada IUPHHK-HA PT Karya Lestari (PT A) dan PT Inhutani II (PT B) masing-masing adalah 16,759 $\mathrm{m} 3$ /pohon dan 6,742 m3/pohon; (2). Rata-rata volume limbah kayu pada PT A dan PT BI masing-masing adalah 2,410 m3/pohon dan 0,472 m3/pohon; (3). Proporsi limbah tunggak, pangkal batang, ujung batang pada PT A dan PT B masing-masing adalah $0 \%, 81,54 \%, 18,46 \%$ dan 70,25\%, 21,78\%, 7,97\%; (4). Rata-rata efisiensi pemanfaatan kayu pada PT A dan PT B masing-masing adalah 88\% dan 86\%; dan (5). Pengaruh potensi limbah pemanenan kayu terhadap efisiensi pemanfaatan kayu ditunjukkan dengan model persamaan $Y=0,971-0,0341 \mathrm{X}$.
\end{abstract}

Kata kunci: Pemanenan kayu, potensi limbah, efisiensi, hutan alam

\begin{abstract}
Potential logging residue from forest harvesting operation is significantly high at tree quantities of logging. This reflects in a low efficient of harvesting that may derive wasteful in using forest resources. In the contrary, the wood supply is not equal to wood demand. The wood supply continously decrease so that it is not able to support the demand of wood industry. The aim of research is to find out the potential logging residue on forest harvesting operation and its effect on wood utilization at two companies in Kalimantan. Research method used by measuring potential forest standingstock, potensial use of wood volume and logging residue from the harvesting operation. The study also measures felling index, skidding index and efficiency of wood utilization. Research result showed that: (1). Average of wood volume used in IUPHHK- HA PT Karya Lestari (PT A) and Inhutani II (PT B) are consecutively 16.759 $\mathrm{m}^{3} /$ tree and $6.742 \mathrm{~m} 3 /$ tree; (2). Average of logging residue PT A and PT B are $2.410 \mathrm{~m}^{3} /$ tree and $0.472 \mathrm{~m}^{3} /$ tree; (3) The percentage of the logging residue at tha bottom stem, middle stem, and upper stem at PT A are $0 \%, 81.54 \%$, $18.46 \%$ and PT B is about 70.25\%, 21.78\%, 7.97\%; (4). The average of timber utilization efficiency (TUE) at PT A and PT B are 88\% and 86\%; and (5). The equation derived from the comparation model between the effect of logging residue from forest harvesting operation and efficiency of wood utilization is $\mathrm{Y}=0.971-0.0341 \mathrm{X}$.
\end{abstract}

Keywords: forest harvesting, potential of logging residue, efficiency, native forest

Sitasi: Suhartana, S dan Yuniawati (2018). Pengaruh Limbah Pemanenan Kayu Terhadap Efisiensi Pemanfaatan Kayu Hutan Produksi Alam Pada Dua Pengusahaan Hutan Di Kalimantan. Jurnal Ilmu Lingkungan, 16(2), 147-154, doi: 10.14710/jil.16.2.147-154.

\section{Pendahuluan}

Kegiatan penebangan kayu di hutan alam sampai saat ini belum mampu meningkatkan efisiensi pemanfaatan kayu, disebabkan banyaknya limbah yang sebenarnya masih dapat dimanfaatkan oleh pengusahaan hutan. Sari dan Ariyanto (2018) menyebutkan bahwa penebangan kayu sebagai salah satu dari rangkaian kegiatan pemanenan kayu memiliki tujuan untuk memaksimalkan nilai kayu dan mengoptimalkan pasokan bahan baku industri. Penebangan merupakan kegiatan yang paling potensial untuk menghasilkan limbah kayu. Keberhasilan penebangan pohon dapat diukur dari tingkat kerusakan terhadap lingkungan dan limbah yang dihasilkan.

Kementerian Lingkungan Hidup dan Kehutanan (2017) menyebutkan bahwa produksi 
Suhartana, S dan Yuniawati (2018). Pengaruh Limbah Pemanenan Kayu Terhadap Efisiensi Pemanfaatan Kayu Hutan Produksi Alam Pada Dua Pengusahaan Hutan Di Kalimantan. Jurnal Ilmu Lingkungan, 16(2), 147-154, doi: 10.14710/jil.16.2.147-154

kayu bulat dari hutan alam Indonesia pada tahun 2016 sebesar $5.429 .543 \mathrm{~m}^{3}$ sedangkan pada tahun 2015 sebesar $5.624 .053 \mathrm{~m}^{3}$, terjadi penurunan produksi sebesar 3,5\% (5.624.053-5.429.543/5.624.053 x 100). Melihat penurunan produksi tersebut maka efisiensi pemanfaatan kayu dari hutan alam harus meningkat dengan meminimalkan limbah penebangan.

Matangaran et al. (2013) menyebutkan bahwa limbah kayu atau limbah pemanenan kayu didefinisikan sebagai kayu yang tidak atau belum dimanfaatkan pada kegiatan pemanenan hutan yang berasal dari pohon yang boleh ditebang berupa sisa pembagian batang, tunggak, ranting dan pucuk. Limbah pemanenan hutan berupa kayu dapat berbentuk tunggak, batang, cabang dan potongan pendek yang dapat terjadi di petak tebang, Tempat Pengumpulan Kayu (TPn) dan Tempat Penimbunan Kayu (TPK).

Efisiensi pemanenan kayu adalah perbandingan antara volume kayu batang bebas cabang yang dimanfaatkan sampai di TPn dengan total volume batang bebas cabang dikalikan 100\%. Sedangkan, yang dimaksud dengan limbah tebang atau disebut juga limbah pemanenan adalah kayu sisa hasil pemanenan kayu yang tidak dimanfaatkan lagi oleh pemegang izin/hak yang sah pada kegiatan pemanenan. Limbah tersebut dapat berasal dari pohon yang ditebang berupa sisa pembagian batang termasuk cabang, ranting, pucuk, tunggak atau sisa kayu batang bebas cabang yang mempunyai ukuran diameter kurang dari $30 \mathrm{~cm}$ atau panjang tidak lebih dari 2 m (Kepmenhut Nomor: 6886/Kpts-II/2002).

Dari jumlah kayu yang ditebang di hutan, hanya sekitar $40 \%$ yang dimanfaatkan untuk industri kayu lapis. Adapun sisanya yang sekitar 60\% ditinggalkan di dalam petak tebang atau TPn. Permasalahan limbah di hutan alam menjadi perhatian yang serius karena bahan baku industri perkayuan semakin lama semakin berkurang. Upaya meminimalkan limbah pemanenan dilakukan sebisa mungkin mencapai zero waste

Limbah pemanenan sering timbul akibat kesalahan teknis di lapangan dan juga akibat kebijakan perencanaan pemanenan yang kurang tepat. Pemanfaatan kayu yang kurang efisien terjadi karena jumlah kayu yang dimanfaatkan pada umumnya masih rendah dibandingkan dengan volume kayu yang ditebang. Besarnya limbah kayu akibat pemanenan hutan secara mekanis sebesar 39.58\% (Muhdi, 2001).

Pengelolaan hutan alam telah menerapkan teknik RIL. Pemanenan kayu dengan menerapkan RIL (Reduced Impact Logging) dapat meningkatkan efisiensi pemanfaatan kayu. Hasil penelitian (Muhdi et al., 2016) menyebutkan bahwa rata-rata persentase pemanfaatan kayu pada penebangan konvensional dan RIL masing-masing adalah 71,56\% dan 81,03\% di mana pemanenan kayu secara konvensional menghasilkan limbah sebesar $16,33 \mathrm{~m}^{3}$ /ha sedangkan secara RIL sebesar $11,06 \mathrm{~m}^{3} /$ ha.

Pemanfaatan hutan secara lebih efisien sebagai upaya menurunkan volume limbah kayu di petak tebang sulit diharapkan terwujud, jika tidak dibarengi dengan kebijakan pemberian insentif dan disinsentif atas pemanfaatan hutan tersebut. Pungutan PSDH dan DR merupakan pungutan yang langsung mempengaruhi perilaku pemegang IUPHHK melalui pengaruhnya terhadap biaya dan laba (Astana et al. 2014).

Bertolak dari latar belakang tersebut maka tulisan ini bertujuan untuk mengetahui potensi limbah pemanenan kayu pada dua pengusahaan hutan alam Kalimantan dan pengaruhnya terhadap efisiensi pemanfaatan kayu.

\section{Metode Penelitian}

\subsection{Waktu, Lokasi dan Bahan Penelitian}

Penelitian pertama dilaksana-kan di IUPHHK-HA PT Karya Lestari (PT A) pada tanggal 09 - 22 Nopember 2015 di areal kerja Blok tebang Carry Over 2014 Petak tebang R.11. Areal ini termasuk ke dalam wilayah Kabupaten Berau, Provinsi Kaliman-tan Timur. Berdasarkan letak geografisnya, kelompok hutan ini terletak di antara 0135'15.6" - 0148'4.4" LU dan $116^{\circ} 40^{\prime} 12.2^{\prime \prime}-116^{\circ} 59^{\prime} 46.7$ "BT.

Penelitian kedua di IUPHHK-HA PT Inhutani II (PT B) areal kerja Unit Sei Tubu, Kabupaten Malinau, Provins Kalimantan Utara pada tanggal 26 Nopember sampai 7 Desember 2015 di petak tebang AC-42. Secara geografis areal kerja terletak pada $115^{\circ} 45^{\prime} 32^{\prime \prime}$ - 116¹5'10" BT dan 2041'21" - 3o13'05” BT.

Bahan yang digunakan dalam penelitian ini adalah sling kabel baja untuk membantu mengikat kayu hasil tebangan, kapur, cat, spidol, plastik untuk label pohon ditebang, solar, minyak pelumas dan lembar pencatatan (tally sheet). Alat yang digunakan dalam penelitian ini adalah gergaji rantai (chainsaw), traktor sarad (skidder), phi-band dan meteran untuk mengukur diameter dan panjang pohon yang ditebang, jam henti (stop watch) untuk mengukur waktu, alat pengukur lereng (clino meter), kompas dan kamera digital untuk dokumentasi.

\subsection{Prosedur penelitian}

1. Penentuan petak contoh

a. Pada petak tebang terpilih di PT A dibuat plot contoh penelitian (PCP) sebanyak 3 buah masing-masing berukuran 2,0 ha (200 x $100 \mathrm{~m})$ sedangkan di PT B dibuat sebanyak 8 PCP dirancang secara systematic sampling with purposive start di mana PCP pertama dilakukan secara purposive pada petak tebang terpilih dan PCP selanjutnya dibuat secara sistematik dengan jarak antar PCP adalah $100 \mathrm{~m}$.

b. Pembuatan PCP dilakukan dengan berpedoman pada peta rencana operasional pemanenan kayu (ROPK) skala 1:50.000. Setelah PCP dibuat, selanjutnya dilakukan inventarisasi tegakan sebelum penebangan (ITSP) pada tegakan berdiameter $20 \mathrm{~cm}$ ke atas untuk semua jenis pohon. Inventarisasi dilakukan untuk memvalidasi laporan hasil cruising (LHC) kegiatan ITSP yang dilakukan perusahaan. 
2. Data yang dikumpulkan

a) Data Sekunder

Data sekunder diperoleh dengan melihat arsip/data yang tersedia di lokasi penelitian, antara lain: kondisi umum IUPHHK-HA (keadaan hutan, letak dan luas areal, topografi, ikilm), LHC, LHP, pelaksanaan grading scalling.

b) Data Primer

Data primer merupakan data pokok yang diperoleh dengan cara pengamatan langsung di lapangan. Adapun data primer yang dikumpulkan adalah volume kayu batang bebas cabang yang dimanfaatkan, limbah kayu yang terdapat di petak tebang, Limbah pada kegiatan penebangan, jalan sarad dan TPn.

1). Limbah penebangan

Data diperoleh dari hasil pengukuran limbah kayu hasil penebangan pada petak tebang yang telah ditentukan. Limbah yang diukur antara lain limbah tunggak, limbah pangkal, limbah ujung dan volume batang bebas cabang yang dimanfaatkan (Gambar 1) (Suhartana, et al. 2016)

Pada setiap pohon yang ditebang diberi nomor kode (atau sesuai label pohon) dan diukur kondisi kemiringan lereng. Yang dimaksud limbah tunggak adalah selisih antara tinggi tunggak dikurangi tinggi tebang yang diijinkan, yaitu 1/3 diameter pohon dbh untuk pohon tidak berbanir (Ward E, 2006). Sedangkan limbah tunggak untuk pohon berbanir dihitung dari selisih antara tinggi tunggak dikurangi dengan tinggi tebang yang diijinkan (yaitu $10 \mathrm{~cm}$ di atas banir). Apabila perhitungan selisih antara tinggi tunggak dan tinggi tebang yang diijinkan negatif berarti limbah tunggak dianggap tidak ada (Gambar 2) (Ward, 2006).

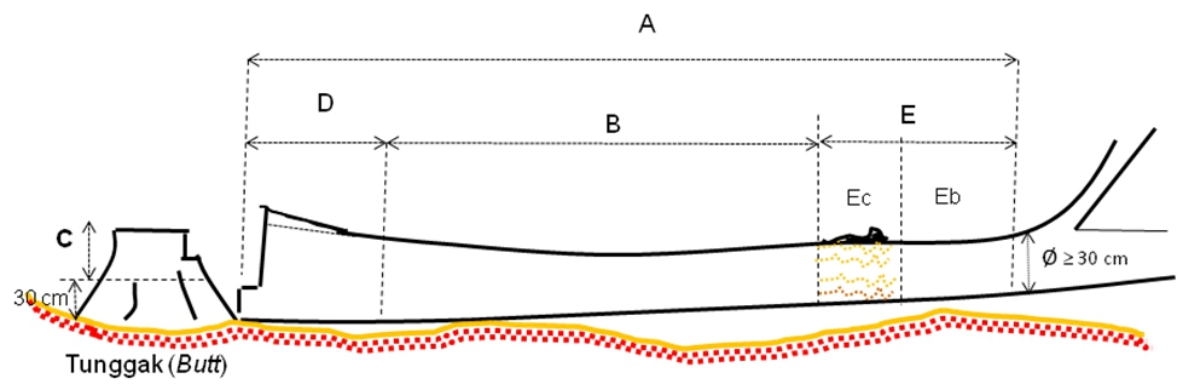

Keterangan : A = Batang bebas cabang (Clear bole); $\mathrm{B}=$ Batang yang dimanfaatkan (Utilized wood) $; \mathrm{C}=$ Limbah tunggak $($ Butt waste $)=$ tinggi tunggak (butt height)-tinggi tebang diijinkan (Allowable height cut); $\mathrm{D}=$ Limbah pangkal $($ Waste base $) ; \mathrm{E}=$ Limbah ujung $($ Top wastes up to $) \mathrm{U}=30 \mathrm{~cm}\{\mathrm{Ec}=$ $\operatorname{cacat}(r o t t), \mathrm{Eb}=$ baik (good)\}; Ec (pecah/break, mata buaya/notch, busuk hati/heart rott, bengkok/bend,growong )hole))

Gambar 1 Pengukuran kayu yang dimanfaatkan dan limbah kayu

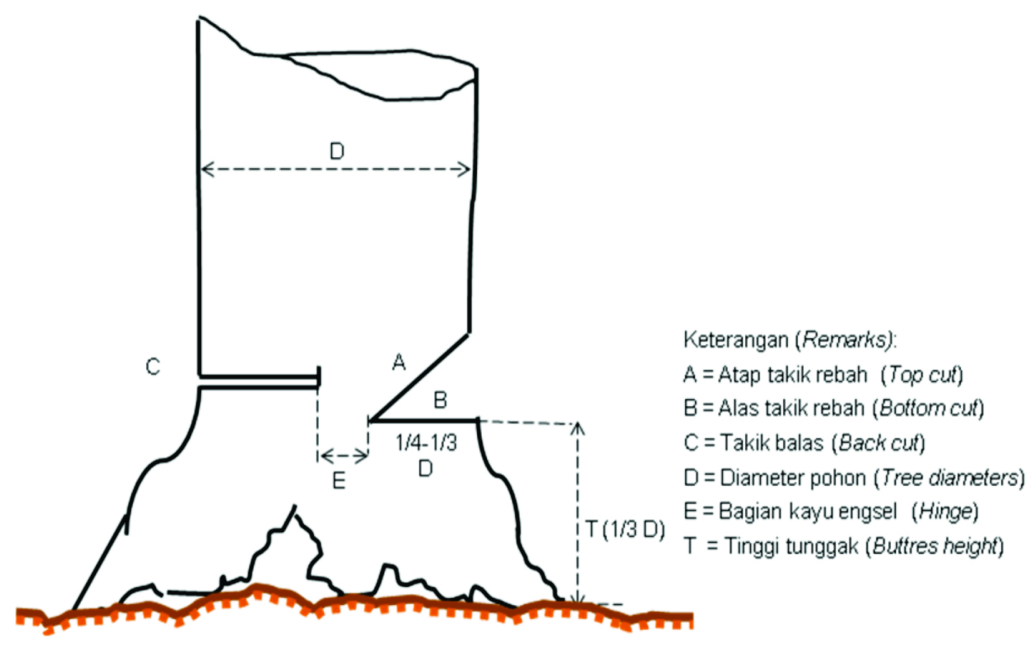

Gambar 2 Ukuran takik rebah

2) Limbah pada kegiatan penyaradan

Data diperoleh dari hasil pengukuran limbah yang terdapat di sepanjang jalan sarad pada plot pengamatan yang telah ditentukan sebelumnya. Limbah kayu yang diukur di jalan sarad adalah bagian batang bebas cabang yang tertinggal di sepanjang jalan sarad karena kondisinya dan atau limbah lain yang dikategorikan sebagai limbah. Dimensi yang diukur adalah jenis limbah, panjang sortimen, diameter limbah, dan kondisi limbah tersebut. 
Suhartana, S dan Yuniawati (2018). Pengaruh Limbah Pemanenan Kayu Terhadap Efisiensi Pemanfaatan Kayu Hutan Produksi Alam Pada Dua Pengusahaan Hutan Di Kalimantan. Jurnal Ilmu Lingkungan, 16(2), 147-154, doi: 10.14710/jil.16.2.147-154

3) Limbah di tempat pengumpulan kayu (TPn)

Data limbah dari TPn yang diukur adalah limbah kayu yang berupa sisa-sisa pemotongan bagian pangkal atau ujung dan batang bebas cabang yang tidak diangkut karena mengandung cacat seperti bengkok, mata buaya, busuk hati, gerowong (berlubang) dan lain-lain. Juga sortimen kayu bulat yang mungkin terdapat di TPn karena kondisinya tidak diangkut. Limbah dan sortimen yang diukur berasal dari pohon yang sama dengan pohon yang diukur di petak tebang. Limbah di TPn terjadi akibat dari kegiatan pemotongan ujung batang (trimming) dan pemuatan kayu ke alat angkut.

\section{Pengolahan data.}

Efisiensi pemanfaatan kayu = indeks tebang $\mathrm{x}$ indeks sarad

Di mana : indeks tebang $=$

volume kayu siap di sarad di petak tebang

Di mana : VL = Volume limbah (m3); Dp = Diameter pangkal $(\mathrm{cm}) ; \mathrm{Du}=$ Diameter ujung $(\mathrm{cm}) ; \mathrm{P}=$ Panjang limbah $(\mathrm{m}) ; \pi=$ Konstanta $(3,14)$

Untuk mengetahui efisiensi pemanfaatan kayu dihitung dengan rumus (Abidin, 1994) sebagai berikut:

indeks sarad $=$

volume batang bebas cabang

volume kayu yang dimanfaatkan di TPn

volume kayu yang disarad sampai TPn

\subsection{Analisis Data}

Untuk mengetahui pengaruh limbah penebangan terhadap efisiensi pemanfaatan kayu dilakukan analisis regresi linier dengan model persamaan : $\mathrm{Y}=\mathrm{a}$ + bX (Janie, 2012), di mana $Y=$ variabel dependent; $a=$ intersept, $\mathrm{b}=$ parameter, $\mathrm{X}=$ Variabel indenpendent. Hipotesis bentuk kalimat dari hasil analisis yaitu $\mathrm{Ha}=$ potensi limbah pemanenan kayu berpengaruh signifikan terhadap efisiensi pemanfaatan kayu. Ho = potensi limbah pemanenan kayu tidak berpengaruh signifikan terhadap efisiensi pemanfaatan kayu. Kaidah keputusan dari hasil analisis yaitu apabila nilai probabilitas $0,05<$ nilai probabilitas sig, maka Ho diterima artinya tidak signifikan dan apabila nilai probabilitas $0,05>$ nilai probabilitas sig, maka Ho ditolak artinya signifikan.

\section{Hasil dan Pembahasan}

\subsection{Rata-rata volume kayu pada areal penelitian}

Hasil pengukuran volume kayu yang dimanfaatkan dan limbah kayu pada PT A dan PT B disajikan pada Tabel 1.

Tabel 1 menunjukkan bahwa rata-rata volume kayu dimanfaatkan pada dua perusahaan memiliki perbedaan sebesar 16,759-6,742/(16,759) x 100\%= $59,77 \%$. Perbedaan tersebut disebabkan oleh ukuran panjang batang dan diameter batang yang berbeda. Pada PT A memiliki rata-rata volume kayu dimanfaatkan ( $\mathrm{m}^{3} /$ pohon) lebih tinggi daripada PT B. Hal ini disebabkan karena rata-rata diameter kayu yang dimanfaatkan masing-masing sebesar 96,73 cm (PT A) sedangkan pada PT B rata-rata ukuran panjang kayu dan diameter kayu yang dimanfaatkan masingmasing sebesar 17,08 m dan 77,87 cm. Dimensi kayu berupa panjang dan diameter kayu yang dimanfaatkan berpengaruh terhadap volume kayu yang dimanfaatkan. Dari dimensi tersebut maka dapat disimpulkan bahwa potensi sebaran tegakan di PT A lebih banyak daripada PT B. Smith (1962) mengemukakan bahwa jumlah batang pada setiap diameter selalu berubah menurut waktu, perubahan tersebut disebabkan adanya kecepatan pertumbuhan diameter pohon dalam kelas diameter dan adanya variasi ruang tumbuh yang diperlukan dalam pertumbuhan pohon.

Tabel 1 menunjukkan bahwa rata-rata volume limbah kayu ( $\mathrm{m}^{3} /$ pohon) PT A lebih tinggi $(2,410$ m3/pohon) daripada PT B $\left(0,472 \mathrm{~m}^{3} /\right.$ pohon $)$. Ada beberapa faktor yang menyebabkan tingginya volume limbah kayu pada perusahaan tersebut, yaitu 1). Kondisi topografi areal penelitian sangat curam dengan rata-rata kemiringan lereng $>40 \%$. Kemiringan lereng ikut mempengaruhi volume limbah kayu yang dihasilkan. Karena terjadinya pecah batang mendominasi pohon yang ditebang pada kelerengan tersebut. Kayu yang seharusnya dapat dimanfaatkan akan menjadi limbah karena pecah batang akibat pohon yang rebah jatuh ke dalam jurang. Kondisi topografi tersebut merupakan kendala bagi operator chainsaw, sehingga limbah pangkal batang juga dapat terjadi. 2). Arah rebah yang salah juga merupakan faktor yang menyebabkan terjadinya limbah. Arah rebah pohon seharusnya mengikuti jalur sarad, tapi kenyataan di lapangan operator chainsaw lebih dominan mengarahkan arah rebah pohon ke jurang. 
3). Keterampilan operator chainsaw juga mempengaruhi besarnya limbah yang dihasilkan. Menggunakan chainsaw, pembuatan takik balas dan rebah, menentukan arah rebah pohon dan pembagian batang merupakan keterampila operator chainsaw yang harus dikuasai dengan baik. 4) Kondisi alat tebang yaitu dimensi alat tebang harus sesuai untuk menebang pohon diameter $>30 \mathrm{~cm}$ terutama besarnya kekuatan mesin dan panjang bar chainsaw.

Hasil penelitian Sari dan Ariyanto (2018) di hutan alam distrik

Tabel 1. Rata-rata volume kayu dimanfaatkan dan limbah kayu pada 2 perusahaan

\begin{tabular}{clcc}
\hline No. & \multicolumn{1}{c}{ Uraian } & $\begin{array}{c}\text { Rata-rata di } \\
\text { PT A }\end{array}$ & $\begin{array}{c}\text { Rata-rata di } \\
\text { PT B }\end{array}$ \\
\hline 1 & Diameter pohon $(\mathrm{cm})$ & 96,73 & 77,87 \\
2 & Panjang sortimen $(\mathrm{cm})$ & 24,49 & 17,08 \\
3 & Volume batang bebas cabang (m3/pohon) & 19,092 & - \\
4 & Volume kayu dimanfaatkan $\left(\mathrm{m}^{3} /\right.$ pohon) & 16,759 & 6,742 \\
5 & Volume limbah kayu (m3/pohon) & 2,410 & 0,472 \\
6 & Volume limbah kayu (\%) & - & 6,66 \\
\hline
\end{tabular}

Berau Kalimantan Timur menunjukkan bahwa total volume pohon yang ditebang adalah $618,7 \mathrm{~m}^{3}$ dan total volume limbah penebangan yang terjadi di areal penebangan adalah $509,7 \mathrm{~m}^{3}$, sedangkan volume ratarata pohon yang ditebang adalah $10,3 \mathrm{~m}^{3}$ dan volume rata-rata limbah yang dihasilkan masing-masing pohon yang ditebang adalah 8,5 m3.

Hasil penelitian Abidin et al., (2017) menunjukkan bahwa persentase limbah yang diperoleh adalah sebesar 14,21\% yang terdiri dari lima jenis kayu yaitu meranti merah, meranti putih, keruing, kapur dan Balau. Limbah ini berdiameter 50 cm hingga $150 \mathrm{~cm}$, dan panjangnya berkisar antara 0,9 meter sampai 4,7 meter. Estimasi pemanfaatan limbah, secara keseluruhan dapat digunakan untuk produk konstruksi perumahan (bantalan, dinding, kuda-kuda, tiang, palang, kusen, kaso), dan Produk veneer, partikel board dan block board.

\subsection{Proporsi limbah penebangan kayu}

Hasil perhitungan distribusi dan proporsi limbah kayu disajikan pada Tabel 2 .

Tabel 2. Proporsi limbah kayu pada dua perusahaan

\begin{tabular}{|c|c|c|c|c|c|}
\hline \multirow[t]{2}{*}{ No. } & \multirow[t]{2}{*}{ Uraian } & \multicolumn{2}{|c|}{$\begin{array}{c}\text { Rata-rata di } \\
\text { PT A }\end{array}$} & \multicolumn{2}{|c|}{$\begin{array}{c}\text { Rata-rata di } \\
\text { PT B }\end{array}$} \\
\hline & & $\mathrm{m}^{3}$ & $\%$ & $\mathrm{~m}^{3}$ & $\%$ \\
\hline 1 & Tunggak & 0 & 0 & 0,332 & 70,25 \\
\hline 2 & Pangkal batang & 1,966 & 81,54 & 0,100 & 21,78 \\
\hline 3 & Ujung batang & 0,445 & 18,46 & 0,040 & 7,97 \\
\hline 4 & Total limbah & 2,411 & 100,00 & 0,472 & 100,00 \\
\hline
\end{tabular}

Tabel 2 menunjukkan bahwa proporsi limbah kayu terjadi pada tunggak, pangkal batang dan ujung batang. Limbah pada tunggak terjadi karena tunggak yang dihasilkan masih terlalu tinggi, hal ini disebabkan rata-rata diameter pohon di hutan alam > $40 \mathrm{~cm}$ dan kondisi banir yang tinggi di atas dada. Limbah pada pangkal batang terjadi akibat kesalahan teknis, seperti kesalahan penggunaan alat tebang sehingga pangkal batang menjadi pecah. Limbah ujung batang terjadi didominasi oleh kondisi pecah dan patah karena rebahnya pohon yang keras menghantam tanah atau batu serta jatuh ke jurang. Total limbah yang terjadi pada PT A sebesar 2,411 m3 lebih tinggi daripada di PT B. Rata-rata tinggi tunggak pada PT A telah memenuhi persyaratan tinggi tunggak yang harus ditinggalkan sehingga diberi nilai nol (0). Wenger (1984) menuliskan bahwa tinggi tunggak yang diijinkan untuk pohon tidak berbanir adalah sepertiga dari diameter setinggi dada sedangkan untuk pohon berbanir tinggi tunggak sampai dengan tinggi banir. Ada 2 faktor penyebab tidak terjadinya limbah tunggak yaitu kondisi pohon yang berbanir dan cara penebangan oleh operator chain saw yang menerapkan teknik penebangan serendah mungkin.

Hasil penelitian Soenarno (2014) di IUPHHK-

HA PT Roda Mas Timber Kalimantan, menunjukkan bahwa besarnya limbah pembalakan batang bebas cabang yang potensial dapat dimanfaatkan adalah $0,357 \mathrm{~m}^{3} /$ pohon $(25,58 \%)$ dari total limbah pembalakan sebanyak $1,395 \mathrm{~m}^{3} /$ pohon atau besarnya limbah pembalakan batang bebas cabang yang potensial dapat dimanfaatkan adalah 0,357 m3/pohon (25,58\%) dari total limbah pembalakan sebanyak 1,395 $\mathrm{m}^{3} /$ pohon atau sebesar $3,02 \%$ terhadap keseluruhan volume batang bebas cabang.

Sedangkan hasil penelitian Wahyuni (2009) di IUPHHK-HA PT. Andalas Merapi Timber menunjukkan bahwa persentase limbah pemanenan kayu pada lokasi penebangan adalah sebesar $45 \%$ dari 
Suhartana, S dan Yuniawati (2018). Pengaruh Limbah Pemanenan Kayu Terhadap Efisiensi Pemanfaatan Kayu Hutan Produksi Alam Pada Dua Pengusahaan Hutan Di Kalimantan. Jurnal Ilmu Lingkungan, 16(2), 147-154, doi: 10.14710/jil.16.2.147-154

125 batang yang diamati (54 batang memiliki limbah dan 66 batang tidak memiliki limbah). Persentase limbah jenis meranti paling tinggi yaitu 21,05\%. Faktor penyebab limbah terdiri dari cacat alami sebesar 70,61\%, cacat mekanis sebesar $11,88 \%$ dan faktor alam (kelerengan) 17,51\%.

\subsection{Efisiensi pemanfaatan kayu hutan alam}

Rekapitulasi dan perhitungan indeks tebang disajikan pada Tabel 3. Tingkat efisiensi penebangan dapat didekati dengan menghitung indeks tebangnya. Tabel 3 menunjukkan bahwa rata-rata indeks tebang pada 2 perusahaan tersebut mendekati hampir sama yaitu 0,92 dan 0,93 angka tersebut dapat dikatakan tinggi.
Indeks tebang diartikan sebagai rasio antara volume siap sarad dengan volume potensial pohon berdiri. Volume siap sarad merupakan volume dari sortimen berkualitas baik yang dihasilkan dari kegiatan pembagian batang. Indeks sarad diartikan sebagai rasio antara volume siap angkut dengan volume siap sarad. Tingginya indek tebang tersebut disebabkan oleh tingginya volume kayu yang siap disarad di petak tebang, hal ini menunjukkan bahwa operator chainsaw memiliki keterampilan yang baik di mana operator chainsaw dalam proses pembagian batang (bucking) sesuai dengan standard operation prosedur perusahaan tersebut.

Tabel 3. Rata-rata efisiensi pemanfaatan kayu pada dua perusahaan

\begin{tabular}{ccc}
\hline Uraian & $\begin{array}{c}\text { Rata-rata di } \\
\text { PT A }\end{array}$ & $\begin{array}{c}\text { Rata-rata di } \\
\text { PT B }\end{array}$ \\
\hline Indeks tebang & 0,92 & 0,93 \\
Indeks sarad & 0,96 & 0,92 \\
Efisiensi pemanfaatan & 0,88 & 0,86 \\
kayu & & \\
\hline
\end{tabular}

Rata-rata Indeks sarad di PT A sebesar 0,96 lebih tinggi daripada di PT B. Hal ini menunjukkan bahwa sebesar 96\% dari volume sortimen siap sarad menghasilkan volume sortimen siap angkut dan sebesar 4\% dari sortimen siap sarad menjadi limbah penyaradan. Sedangkan pada PT B rata-rata indeks sarad sebesar 0,92 sehingga volume sortimen siap sarad lebih rendah daripada PT A dengan limbah sarad sebesar $8 \%$.

Tabel 4. Model Summary hubungan potensi limbah pemanenan kayu terhadap efisiensi pemanfaatan kayu di PT A

\begin{tabular}{|c|c|c|c|c|}
\hline Model & $\mathrm{R}$ & Koefisien determinasi $\left(\mathrm{R}^{2}\right)$ & $\begin{array}{c}\mathrm{R}^{2} \text { yang } \\
\text { disesuaikan }\end{array}$ & Standar kesalahan perhitungan \\
\hline 1 & $0,940^{\mathrm{a}}$ & 0,883 & 0,880 & 0,03344 \\
\hline
\end{tabular}

Dari indeks tebang dan indeks sarad tersebut dapat diketahui nilai efisiensi pemanfataatan kayu. Ratarata efisiensi pemanfaatan kayu pada PT A lebih tinggi daripada PT B, dapat dikatakan bahwa sebanyak 88\% kayu dapat dimanfaatkan dan $12 \%$ merupakan limbah. Tingginya efisiensi tersebut dikarenakan ratarata volume kayu yang dimanfaatkan lebih tinggi daripada rata-rata potensi limbah. Keterampilan operator sangat berperan terhadap efisiensi tersebut. Hasil penelitian Zuhrianto (2016) menunjukkan bahwa limbah penebangan didominasi oleh limbah batang di bawah cabang pertama sebesar $48.64 \%$ diikuti limbah batang di atas cabang pertama $28.88 \%$, tunggak 18.61\%, dan dahan 3.87\%. Efisiensi pemanenan kayu untuk pemanfaatan pohon keseluruhan rata-rata sebesar $67.28 \%$ dan limbah rata-rata yang dihasilkan sebesar $32.72 \%$. Pemanfaatan bebas cabang rata-rata sebesar $75.69 \%$ dan limbah rata-rata yang dihasilkan sebesar $24.31 \%$. Efisiensi yang diperoleh tidak dipengaruhi oleh jenis pohon yang ditebang dan keterampilan operator. Potensi volume limbah yang diperoleh sebesar 5.27 m3 untuk setiap pohon yang ditebang dan $0.52 \mathrm{~m}^{3}$ untuk setiap $1 \mathrm{~m}^{3}$ yang dimanfaatkan.

Hasil analisis pengaruh potensi limbah pemanenan kayu terhadap efisiensi pemanfaatan kayu pada IUPHHK-HA PT A disajikan pada Tabel 4,5 dan 6.

Tabel 5. Analisis Anova hubungan potensi limbah pemanenan kayu terhadap efisiensi pemanfaatan kayu di PT A

\begin{tabular}{|c|c|c|c|c|c|c|}
\hline & Model & Jumlah kuadrat & $\begin{array}{c}\text { Derajat } \\
\text { bebas }\end{array}$ & $\begin{array}{l}\text { Rata-rata } \\
\text { kuadrat }\end{array}$ & F hitung & Peluang \\
\hline \multirow[t]{3}{*}{1} & Regresi & 0,320 & 1 & 0,320 & 286,648 & $0,000^{a}$ \\
\hline & Sisa & 0,420 & 38 & 0,001 & & \\
\hline & Total & 0,363 & 39 & & & \\
\hline
\end{tabular}

a. Predictors: (Constant), Potensi_limbah

b. Variabel bergantung: Efisiensi_pemanfaatan 
Tabel 4 menerangkan besarnya korelasi (R), koefisien determinasi (R2), R2 yang disesuaikan dan standar error. Besarnya R2 yang disesuaikan sebesar 0,880 , hal ini menunjukkan bahwa $88,0 \%$ potensi limbah pemanenan kayu dapat dijelaskan oleh variabel efisiensi pemanfaatan kayu, sedangkan sisanya $100 \%-88,0 \%=12,0 \%$ dijelaskan oleh sebab lain.

Tabel 5 menunjukkan bahwa $\mathrm{F}$ hitung memiliki nilai probabilitas lebih kecil daripada taraf kesalahan $(0,000<0,05)$ maka dapat disimpulkan bahwa model persamaan $\mathrm{Y}=\mathrm{a}+\mathrm{bX}$ yang diajukan dapat diterima. Pada Tabel 6 Hasil dari uji koefisien menunjukkan nilai konstan sebesar 0,971 dan nilai B sebesar 0,0341 serta nilai peluang sebesar 0,000. Dari Tabel tersebut diperoleh persamaan regresi sederhana yaitu $\mathrm{Y}=0,971-0,0341 \mathrm{X}$. Konstan sebesar 0,971 menyatakan bahwa jika tidak ada potensi limbah, maka efisiensi pemanfaatan kayu sebesar 97,1\%. Koefisiensi regresi sebesar -0,0341 menyatakan bahwa variabel potensi limbah $(-0,0341)$ berpengaruh negatif terhadap efisiensi pemanfaatan kayu artinya jika variabel efisiensi pemanfaatan kayu meningkat 1 satuan maka potensi limbah akan berkurang sebesar 0,0341 satuan.

\section{Kesimpulan}

- Rata-rata volume kayu yang dimanfaatkan pada PT A dan PT B masing-masing adalah 16,759 $\mathrm{m}^{3} /$ pohon dan $6,742 \mathrm{~m}^{3} /$ pohon.

- Rata-rata volume limbah kayu pada PT A dan PT B masing-masing adalah 2,410 $\mathrm{m}^{3} /$ pohon dan $0,472 \mathrm{~m}^{3} /$ pohon.

○ Proporsi limbah tunggak, pangkal batang, ujung batang pada PT A dan PT B masing-masing adalah $0 \%, 81,54 \%, \quad 18,46 \%$ dan $70,25 \%$, 21,78\%, 7,97\%.

- Rata-rata efisiensi pemanfaatan kayu pada PT A dan PT B masing-masing adalah 88\% dan $86 \%$.

○ Pengaruh potensi limbah pemanenan kayu terhadap efisiensi pemanfaatan kayu ditunjukkan dengan model persamaan $\mathrm{Y}=0,971$ $-0,0341 X$.

\section{Ucapan terima kasih}

Penulis mengucapkan terima kasih kepada pihak PT Karya Lestari dan PT Inhutani II yang telah membantu pelaksanaan penelitian di lapangan.

\section{Daftar Pustaka}

Abidin, R. 1994. Pengendalian manajemen pengusahaan hutan. Fakultas Kehutanan. Bogor. Institut Pertanian Bogor.

Abidin, Z.A., Thamrin, G.T.A.R. dan Silaban, C. 2017. Potensi limbah pemanenan kayu di lokasi penebangan IUPHHK-HA PT. Dasa Intiga Kalimantan Tengah. Jurnal Hutan Tropis, 5 (2) :174-181.

Astana, S., Soenarno, dan Karyono, O.K. 2014. Implikasi perubahan tarif dana reboisasi dan provisi sumberdaya hutan terhadap laba pemegang konsesi hutan dan penerimaan negara bukan pajak: Studi kasus hutan alam produksi di Kalimantan Timur, Indonesia. Jurnal Sosial Ekonomi Kehutanan, 11 (3) : 251- 264.

Direktorat Jenderal Pengusahaan Hutan. 1993. Petunjuk Cara Pengukuran dan Penetapan Isi Kayu Bulat Rimba Indonesia. Jakarta: Direktorat Jendral Pengusahaan Hutan.

Janie, D.N.A. 2012. Statistik Deskriptif \& Regresi Linier Berganda Dengan Spss. (Editor: Dr. Hj. Ardiani Ika S, SE, MM, Ed.). Semarang: Semarang University Press.

Kementerian Lingkungan Hidup dan Kehutanan 2017. Statistik Lingkungan Hidup dan Kehutanan Tahun 2016. Pusat Data dan Informasi Sekretariat Jenderal Kementerian Lingkungan Hidup dan Kehutanan. HImn. 382.

Keputusan Menteri Kehutanan nomor : 6886/KptsII/2002 Tentang Pedoman dan tata cara pemberian izin pemungutan hasil hutan (IPHH) pada hutan produksi. Jakarta, 12 Juli 2002.

Matangaran, J.R., Partiani, T. dan Purnamasari, D.R. 2013. Faktor eksploitasi dan kuantifikasi limbah kayu dalam rangka peningkatan Efisiensi pemanenan hutan alam. Jurnal Bumi Lestari, 13(2):384-393.

Muhdi. 2001. Studi kerusakan tegakan tinggal akibat pemanenan kayu dengan teknik pemanenan berdampak rendah dan konvensional di hutan alam. Studi kasus di HPH Kalimantan Barat. Tesis. Bogor. Fakultas Pasca Sarjana Institut Pertanian Bogor.

Muhdi, Elias, Murdiyarso, D., and Matangaran, J.R. 2016. Wood Waste Caused by Reduced Impact Logging in Indonesian Selective Cutting and Planting System, North Borneo, Indonesia. International Journal of Sciences : Basic and Applied Research (IJSBAR), 30 (1) : 86-92.

Sari, D.R. and Ariyanto. 2018. The potential of woody waste biomass from the logging. Activity at the natural forest of Berau District, East Kalimantan. 1st International Conference on Tropical Studies and Its Application (ICTROPS) IOP Publishing IOP Conf. Series: Earth and Environmental Science 144 (2018) 012061 doi :10.1088/17551315/144/1/012061. Pp: 1-8.

Smith, D.M. 1962. The practice of silviculture. Seventh edition. New York. John Willey and Sons Inc.

Soenarno. 2014. Efisiensi pembalakan dan kualitas limbah pembalakan Di hutan tropika pegunungan: Studi Kasus di IUPHHK-HA PT Roda Mas Timber Kalimantan. Jurnal Penelitian Hasil Hutan, 32 (1): 45-61.

Suhartana, S., Dulsalam, Soenarno, Yuniawati dan Basari, Z. 2016. Faktor eksploitasi di PT. Inhutani II. Bogor : Pusat Litbang Hasil Hutan $36 \mathrm{Hlm}$

Wahyuni. 2009. Potensi limbah pemanenan kayu di lokasi penebangan IUPHHK-HA PT. Andalas Merapi. Skripsi. Fakultas Pertanian. Universitas Sumatera Utara. HIm. 1-67.

Ward, E. 2006. Chain Saws - Safety, Operation, Tree 
Suhartana, S dan Yuniawati (2018). Pengaruh Limbah Pemanenan Kayu Terhadap Efisiensi Pemanfaatan Kayu Hutan Produksi Alam Pada Dua Pengusahaan Hutan Di Kalimantan. Jurnal Ilmu Lingkungan, 16(2), 147-154, doi: 10.14710/jil.16.2.147-154

Felling techniques. Kansas Forest Service. Kansas State University.

Wenger, K.F. 1984. Forestry handbook 2ndedition. John Willey Sons, Inc. Nwe York. USA.

Zuhrianto, T.I. 2016. Limbah dan efisiensi pemanenan kayu di IUPHHK-HA PT Salaki Summa Sejahtera Pulau Siberut, Sumatera Barat. Skripsi. Fakultas Kehutanan. Institut Pertanian Bogor. HIm. 1-29. 